\title{
絶縁液体中の微分ショットキー電流
}

\author{
正員谷 藤 七 郎 (芝浦工大) \\ 正負野末 鉄 有 (芝浦工大)
}

\section{Incremental Shottoky Current and Associated Negative Ion Current in Dielectric Liquid}

Shichiro Tanifuji, Member, Tetsuari Nozue, Member (Shibaura Institute of Technology)

\section{キーワード：絶縁液体, 微分ショットキ一電流, 高電界過渡伝導電流, プリストレス}

著者らは以前加ら液体中の直流高電界伝導現象につ いて研究(1)(2)を行っており, その伝導特性はショット キ一放出の式に従っていることを示してきた ${ }^{(3)}$ が，パ ルス電圧印加時の過渡伝導電流の測定は吸収電流が大 きすぎて不可能であった。本報告では，この過渡伝導 電流特性を解明する手法として，新しく導入した概念 である微分ショットキー電流とその测定法について述 べる。実験で検出される電流は次の量である。

$$
j=\sigma E+\varepsilon_{0} \frac{\partial E}{\partial t}+\frac{\partial P}{\partial t}
$$

高電界をプリストレスしておくことで分極 $P$ を飽和 させて扔き，更に電界 $E$ の時間微分の項はシェーリ ングブリッジを用いて除去すれば，第 1 項の伝導電流 の項のみを測定できる。この第 1 項の電流をショット キー放出電子によるものとみるのである。

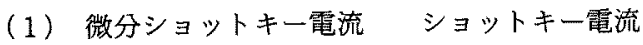
は次式で与えられる。

$$
\begin{aligned}
& I=I_{D} \exp \left(\beta_{s} \sqrt{E}\right)
\end{aligned}
$$

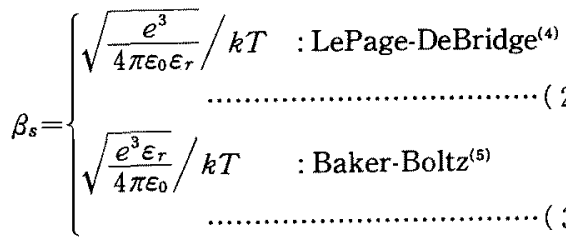

ここに, $I_{D}: E=0$ のきの $I$ の值 (Dushmann の式), $E$ : 陰極面の電界, $e:$ 電子電荷, $\varepsilon_{r}:$ 比誘電率, $k:$ ボルツマン定数, $T:$ 絶 対温度

$\beta_{s}$ についての $(2)$ 式の值は, 液体と陰極が理想的な 接触をしている場合であり，（3）式の值は境界に気体 層を挟んだような境界層をもつ場合の值である。実験
結果では(3)式の值をもつことが示され(1)(5), 境界層 が ( 2 )式で期待する簡単なものではなく, 複雑なもの になっている(5)ことをうかがわせる。

陰極面電界 $E$ として, 一定電界 $E_{0}$ に微少パルス電 界 $\Delta E$ を重疊させた場合を考える。この電界 $\Delta E に$ よるショットキ一電流の増分を微分ショットキ一電流 と呼ぶことにする。ここで, 実験条件を

$$
\Delta E \ll E_{0}, \quad \beta_{s} \Delta E / 2 \sqrt{E_{0}} \ll 1
$$

に設定すると

$$
\begin{aligned}
I & =I_{D} \exp \left(\beta_{s} \sqrt{E}\right)=I_{D} \exp \left(\beta_{s} \sqrt{E_{0}+\Delta E}\right) \cdots(5 \mathrm{a}) \\
& \simeq I_{D} \exp \left(\beta_{s} \sqrt{E_{0}}\right)\left(1+\frac{\beta_{s}}{2 \sqrt{E_{0}}} \Delta E\right) \cdots \cdots \cdots \cdots(5 \mathrm{~b})
\end{aligned}
$$

となり，微分ショットキー電流は $\Delta E$ に比例する。 㓌極表面加ら放出された電子は，液体分子や不純物に 捕捉されるまでは電子性キャリヤとして振舞い, 捕足 されてはじめてイオン性キャリヤとなる。

（2）電子電流とイオン電流の波形上述の上う にして, 液体中に放出された微分ショットキ一電子群 の伝導モデルを次のように考える。図 1 はその説明図 である。

プリストレス $E_{0}$ の状態で放出電流とバルク電流と の間で保たれていた平衡が，じょう乱パルス $\Delta E の$ 印加により破られて微分ショットキ一電子群が放出さ れ，初期ピーク電流 $I_{e 0}(a$ 点)を形成する。後続の電 子群は先発の電子群によるポテンシャルの山などによ り放出を抑制される(6)。この状態下で, 定常漏れ電流 と呼ばれる微少電流になるまで， $E_{0}+\Delta E$ の電界下で の新しい平衡の成立が図られる方向で現象が推移す る。この過程は電子的キャリヤの移動現象として行わ れる。ゆえに近似的に最初の電子群のみが $\delta$ 関数的 


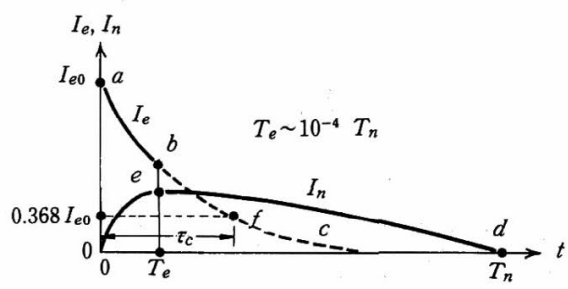

図 1 微分ショットキー電流と負イオン電流

Fig. 1. Electron current and ion current.

に液中に放出されると考え得る。この電子群は負イオ ンを形成しつつ陽極に向かい走行する。その電子捕捉 過程 $(a \rightarrow b \rightarrow c)$ の緩和時間を $\tau_{c}$ とする。この過程の 途中で電子が全部電極間げきを渡り終る ( $b$ 点) と, そ の時刻 $T_{e}$ 以後は電子電流 $I_{e}$ は消失する。一方, この 時刻には電極間げき $d$ 内で形成されたイオン総数は 最大になっており, 負イオン電流は最大 $(e$ 点)であ る。イオンの移動速度 $u_{n}$ は電子のそれ $u_{e}$ の約 $10^{-4}$ 倍であるから，イオンのトランジット時間 $T_{n}(d$ 点) は電子のそれ $T_{e}$ の約 $10^{4}$ 倍となる。

このようなモデルにより電子電流 $I_{e}$ と負イオン電 流 $I_{n}$ の波形を数式で表すと次式のようになる(7)。

$$
\begin{aligned}
& I_{e}=\left\{\begin{array}{cc}
\frac{e n_{0} u_{e}}{d} \varepsilon^{-\eta u_{e} t} & : 0<t<T_{e} \cdots(6 \mathrm{a}) \\
0 & : T_{e}<t \cdots \cdots \cdots(6 \mathrm{~b})
\end{array}\right. \\
& I_{n}=\left\{\begin{array}{cc}
\frac{e n_{0} u_{n}}{d}\left(1-\varepsilon^{-\eta u_{e} t}\right) & : 0<t<T_{e} \cdots(7 \mathrm{a}) \\
\frac{e n_{0} u_{n}}{d}\left(1-\varepsilon^{-\eta\left(d-u_{n} t\right)}\right) & : T_{e}<t<T_{n} \cdots(7 \mathrm{~b}) \\
0 & : T_{n}<t \cdots \cdots \cdots(7 \mathrm{c})
\end{array}\right.
\end{aligned}
$$

ここで, $n_{0}$ : 初期注入電子数, $u_{e} u_{n}$ :それ ぞれ電子およびイオンの移動速度, $e$ : 電子 電荷, $T_{e}, T_{n}$ : それぞれ電子およびイオン の電極間走行時間

実験的にこれらの波形を観測することにより次の諸 量を測定できる。

$$
I_{e o}=e n_{0} / T_{e}: \text { 微分ショットキー電流初期値 }(a
$$

$\tau_{c}=1 / \eta u_{e}:$ ( $f$ 点), $\tau_{n}=1 / \eta u_{n}$

$T_{e}=d / u_{e} \quad:$ ( $b$ 点), $T_{n}=d / u_{n}:$ ( $d$ 点)

これらの測定值から初期注入電子数 $n_{0}$, 電子とイオ ンの移動度 $\mu_{e}$ と $\mu_{n}$, 電子付着係数 $\eta$, 電子が陰極か ら放出されて負イオン化するまでの平均移動行程 $\lambda_{e}$ とイオンの平均自由行程 $\lambda_{n}$ を計算し得る。

（3）微分ショットキー電流波形の例

図 2 は前

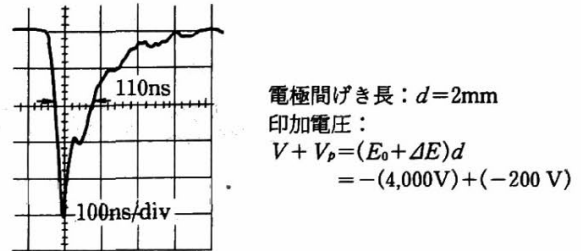

図 2 微分ショットキー電流波形の測定例

Fig. 2. An oscillogram of electron current.

述したシェーリングブリッジを用いて変圧器油中で観 測した微分ショットキー電流波形の一例である。この ことから, 本手法を導入すれば高電界過渡伝導電流を 高精度で測定できることが明らかになった。

今後は, 微分ショットキー電流波形を観測して $n_{0}$, $\tau_{c}, T_{e}$ などの諸物理量を求め, 電子電流, イオン電 流のモデル波形を算出し, 液体中の高電界伝導現象, 界面現象などの解明を進めていく予定である。

なお,この研究には(財) 吉田育英会の援助を得たこ とを付記して謝意を表する。

(平成 2 年 9 月 3 日受付)

\section{文献}

（1）例えば, 谷藤・岳田・岩竹：「液体中の導電(III) 破壊近くの 導電特性」, 昭 33 電気四学会連大, No. 96

（2）谷藤・野末：「絶縁油の電子性微分吸収電流」, 電気学会放電 研資, ED-86-149（昭 61）

（3）谷藤・野末：「液体中の高電界伝導(ショットキー型電子放出 の梚討) 」, 昭 56 電気学会全大, No. 154

(4) W. R. LePage \& L. A. DeBridge: "Electron Emission into Dielectric Liquids", Phys. Rev., 58, 61 (1940)

(5) E. B. Baker \& H. A. Boltz: "The thermionic Emission into Dielectric Liquids", ibid., 51, 275 (1937)

（6）例えば; 中村・酒井・金子・沢田・田頭：「極低温混合液体中 への光電子注入」, 電気学会放電研資, ED-87-52（昭 62）

（7） 谷藤：「電子付着機構のみの場合の電子伝導」, 未発表

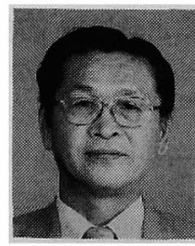

\section{谷 藤 七 郎 (正員)}

昭和 5 年 3 月 11 日生。 30 年 3 月 東北大学大学院工学研究科修士課程 修了。同年 4 月芝浦工業大学電気工 学科助手, 現在, 同助教授。

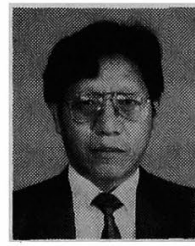

\section{野 末 鉄 有 (正員)}

昭和 16 年 12 月 16 日生。 42 年 3 月芝浦工業大学大学院工学研究科修 士課程修了。同年 4 月, 同大学同学 科助手, 現在, 同講師。 